\title{
Standardization of 2-phenoxyethanol as anesthetic for juvenile Brycon cephalus (Gunther, 1869): the use in field procedures
}

\author{
Padronização no uso do anestésico 2-phenoxyethanol para juvenis de matrinxã Brycon \\ cephalus (Gunther, 1869) em procedimentos de campo
}

\author{
Luis Antônio Kioshi Aoki Inoue ${ }^{1}$ Cristiano dos Santos Neto ${ }^{2}$ Gilberto Moraes ${ }^{3}$
}

\section{- NOTA -}

\section{ABSTRACT}

Hyper motility is a negative factor in fish handling procedures due to the risks of damages to the animals. Chemicals are widely used to anesthetize fish during biometry and many other handling procedures. 2-Phenoxyethanol is largely employed, but many studies are necessary about tropical fish responses. The present research evaluated the anesthesia induction time for juvenile matrinxa submitted to eight different levels of 2-phenoxyethanol. The range of 2-phenoxyethanol concentration was 250-600mg liter ${ }^{-1}$. Induction time of anesthesia decreased as a function of 2-phenoxyethanol concentrations. Fish were safely anesthetized approximately after one minute of exposure to 2-phenoxyethanol batches in concentrations above $400 \mathrm{mg} / \mathrm{liter}$, and the recover period was about one minute for all anesthetic concentrations. 2-Phenoxyethanol is a safe anesthetic for juvenile matrinxã even in exposures up to $600 \mathrm{mg}^{\text {liter }}{ }^{-1}$ being recommended for many field procedures of fish handling.

Key words: 2-phenoxyethanol, anesthetic, Brycon cephalus, matrinxã.

\section{RESUMO}

Em muitos procedimentos de campo que englobam a manipulação de peixes vivos, os animais sofrem grandes riscos de se machucarem devido aos excessivos movimentos que realizam fora da água, sendo necessária a contenção dos animais através do uso de anestésicos. O 2-phenoxyethanol é um produto químico amplamente utilizado no país, sendo, entretanto ainda necessários mais estudos a respeito das respostas fisiológicas dos peixes tropicais às suas propriedades anestésicas. O presente trabalho avaliou o tempo de indução à anestesia de juvenis de matrinxã submetidos a oito diferentes concentrações de 2-phenoxyethanol. O tempo de indução à anestesia diminuiu em função das concentrações do anestésico testado no intervalo de 250-600mg litro $^{-1}$. Os peixes foram anestesiados com segurança após um minuto, em banhos de 2-phenoxyethanol em concentração superior a $400 \mathrm{mg}$ litro $^{-1}$. O período de recuperação dos animais foi de aproximadamente um minuto para todas as concentrações testadas. O 2-phenoxyethanol é um anestésico seguro para juvenis de matrinxã mesmo em elevadas concentrações até $600 \mathrm{mg}^{\text {litro }}{ }^{-1}$.

Palavras-chave: 2-phenoxyethanol, anestésico, Brycon cephalus, matrinxã.

Fish hyper motility impairs handling in fisheries and fish biology procedures. Some accidents may occur whether fish are not efficiently immobilized during biometry, injections, tags, and surgeries. Besides, fish are likely to succumb due to body surface damages as health conditions are disfavored. Pathogens may also take advantage of fish debility as fish may surrender to death (DURVILLE \& COLLET, 2001). The use of anesthetics is frequent to prevent these negative consequences, and 2-phenoxyethanol is fairly applied as fish anesthetic in Brazil due to its safety and non-toxic secondary effects. However, there are few available data about the responses of Neotropical fishes to anesthetics as 2-phenoxyethanol. The concentration of anesthetics needs to be minimum but in effective levels during handling of commercial species as matrinxã Brycon cephalus (GUNTHER, 1869). This fish is widely reared and consumed in Brazil (SAINT-PAUL, 1986) due to many reasons as: excellent growth performance, high adaptability to artificial feeding (CYRINO et al., 1986), and wellfitted behavior to sport fishing. In the present work 2-

\footnotetext{
${ }^{1}$ Engenheiro Agrônomo, Mestre em Aqüicultura, Bolsista CNPq (Processo 141595/01-9), Doutorando no Programa de Pós-graduação em Genética e Evolução, Universidade Federal de São Carlos.

${ }^{2}$ Doutor em Ciências, Professor Adjunto, Departamento de Ecologia e Biologia Evolutiva, Universidade Federal de São Carlos.

${ }^{3}$ Doutor em Ciências, Professor Adjunto, Departamento de Genética e Evolução, Universidade Federal de São Carlos, CP 676, 13565905, São Carlos, SP, Brasil. Corresponding author. Telephone +55-16-2608376, Fax +55-16-2608377. E-mail: gil@power.ufscar.br
} 
phenoxyethanol was evaluated as anesthetic for juvenile matrinxã to control hyper motility during the handling procedure of biometry.

Fish from the same brood were initially stocked in 2,000 liters fiberglass tanks in a closed water flow system. The experimental glass aquaria were always independently filled with 4 liters of aerated freshwater and 2-phenoxyethanol (Sigma $\left.{ }^{\hat{a}}\right)$ to final concentration of 250, 300, 350, 400, 450, 500, 550, and $600 \mathrm{mg} \mathrm{liter}^{-1}$. Three fish per aquarium were individually anesthetized, and anesthesia was carried out from the lowest to the highest concentration. The time to induce stage 3 of anesthesia (TIS3) was measured in seconds. According to WOODY et al. (2001), stage 3 of anesthesia is achieved when fish completely lose the equilibrium and are unable to return to the upright position. In order to simulate field procedures, fish were measured under anesthesia and transferred to recover in a freshwater tank with the same conditions as in the beginning of the experiment. Previous studies established $250 \mathrm{mg} \mathrm{liter}^{-1}$ of 2phenxyethanol as minimum concentration to anesthetize juvenile matrinxã in less than 10 minutes. Every assayed concentration of 2-phenoxyethanol led fish to stage 3 of anesthesia, and TIS3 was predictable (Figure 1) through the mathematical function: $\mathrm{T}=10^{7.01}$ $\mathrm{x}^{-1.94}(\mathrm{~T}=$ time in seconds, $\mathrm{p}=2$-phenoxyethanol concentration in $\mathrm{mg}$ liter $\left.^{-1}\right)$. The use of 2 phenoxyethanol restrained hyper motility of juvenile matrinxã; accidents and fish injuries were prevented consequently. This procedure properly allowed the biometry (mean \pm standard deviation of weight $=107$

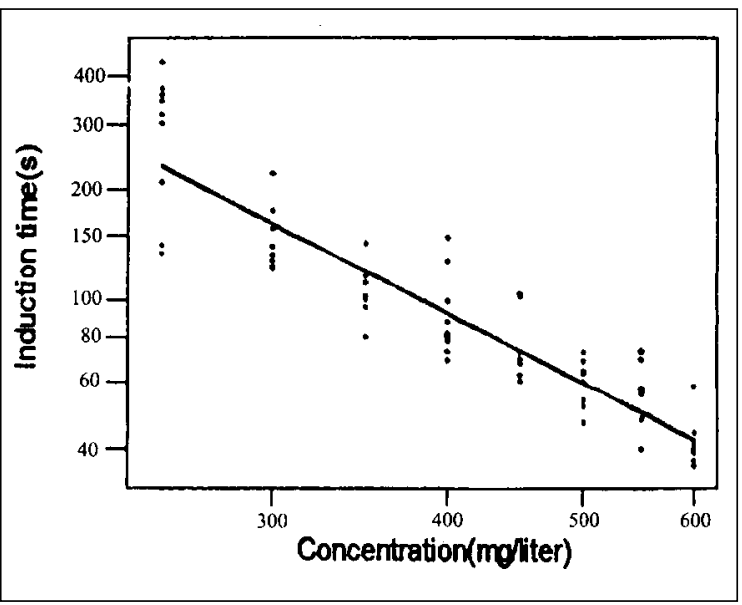

Figure 1 - Mathematical arrangement of the anesthetic effect of 2phenoxyethanol on juvenile matrinxã. $\mathrm{T}=10^{7.01} \mathrm{x} \mathrm{p}^{-1.94}$ as $\mathrm{T}=$ time (s) to reach stage 3 of anesthesia and $\mathrm{p}=2$ phenoxyethanol concentration (mg/liter). $\mathrm{F}=355.660$ and $\mathrm{R}^{2}=83.6 \%$. $\pm 26 \mathrm{~g}$ and length $=20.2 \pm 1.6 \mathrm{~cm})$, one of the most important aquaculture handling procedure to manage growth, feeding, and others. After biometry, all fish satisfactorily regained equilibrium after approximately 1 minute of recovery in clean water, independently of the anesthetic concentration. Mortality was not observed due to handling procedures or anesthesia, even in the course of one month after the experiments.

The 2-Phenoxyethanol revealed to be safe as fish anesthetic, and fish recovered from the maximum exposure concentration of $600 \mathrm{mg} \mathrm{liter}^{-1}$. Other products such as benzocaine, eugenol, MS222 and quinaldine did not allow levels like that showing narrower ranges of safe concentrations to anesthetize tropical fish (GOMES et al., 2001, ROUBACH \& GOMES, 2001, ROUBACH et al., 2001, SLADKY et al., 2001).

The uptake of 2-phenoxyethanol results in spreading of the anesthetic throughout many tissues. KOJIMA et al. (1987) detected 2-phenoxyethanol in the brain, liver, kidney, gall bladder, and especially in the cerebellum of rainbow trout (Salmo gairdneri) after anesthesia. However, 2-phenoxyethanol was also quickly eliminated and the half-life time was achieved in 30 minutes. No evident risks were observed to the operators (ROUBACH \& GOMES, 2001) in the course of biometry, and 2-phenoxyethanol is still further used in pharmacy, perfumery and cosmetics (NATIONAL TOXICOLOGY PROGRAM, 2002). Besides, it has antiseptic properties, which make it recommended for fish handling (ROUBACH \& GOMES, 2001). In conclusion, 2-phenoxyethanol is safe to anesthetize juvenile matrinxã for fisheries purposes. Even exposures to concentrations up to 600 $\mathrm{mg} /$ liter were still secure to juvenile matrinxã, but efficient anesthesia was achieved in concentrations above $400 \mathrm{mg} /$ liter.

\section{REFERENCES}

CYRINO, J.E.P.; CASTAGNOLLI, N.; PEREIRA-FILHO, M. Digestibilidade da proteína de origem animal e vegetal pelo matrinxã (Brycon cephalus GUNTHER, 1869) (Eusteiostei, Characiformes, Characidae) In: SIMPÓSIO BRASILEIRO DE AQUiCulturA, 4., 1986, Cuiabá. Anais... Cuiabá : Universidade Federal de Mato Grosso, Funep, 1986. p. 49-62.

DURVILLE, P.; COLLET, A. Clove oil used as an anesthetic with juvenile tropical marine fish. SPC Live Reef Fish Information Bulletin, Saint-Gilles Les Bains, n.9, p. 17-19, 2001.

GOMES, L. et al. Efficacy of benzocaine as an anesthetic in juvenile tambaqui Colossoma macropomum. Journal of world aquaculture society, v. 32, n. 4, p. 426-431, 2001. 
KOJIMA, H.I.; TAKASHIMA, F.; YOSHIDA, T. Absorption, distribuition and excretion of 2 phenoxyethanol in rainbow trout. Japanese Society of Fisheries Science, Tokyo, v. 53, n. 8, p. 1339-1342, 1987.

NATIONAL TOXICOLOGY PROGRAM. Identifiers of 2 Phenoxyethanol. Capturado em 29 Jul. 2002. Online. Disponível na Internet http://ntpserver.niehs.nih.gov/

ROUBACH, R.; GOMES, L. Uso de anestésicos durante o manejo de peixes. Panorama da Aqüicultura, v. 11, n. 66, p. 37-40, 2001 .

ROUBACH, R.; GOMES, L.; VAL, A. Safest level of tricaine methanesulfonate (MS 222) to induce anesthesia in juveniles of matrinxã Brycon cephalus. Acta Amazonica, v. 31, n. 1, p.159163, 2001.

SAINT-PAUL, U. Potential for aquaculture of South American freshwater fishes: a review. Aquaculture, v. 54, p.205-240, 1986.

SLADKY, K. et al. Comparative efficacy of tricaine methanesulfonate and clove oil for use as anesthetics in red pacu (Piaractus brachypomus). American Journal of Veterinary Research, v. 62, n. 3, p.337-342, 2001.

WOODY, C.A.; NELSON, J.; RAMSTAD, K. Clove oil as an anaesthetic for adult sockeye salmon: field trails. Journal of Fish Biology, v. 69, p. 340-347, 2001. 